\title{
Peningkatan Keterampilan Menulis Puisi Berbahasa Jawa (Geguritan) Melalui Media VCD Peristiwa Menyentuh Hati dan Teknik Tangpitu (tangkap, pikir, tulis) pada Siswa Kelas IXA SMP Negeri 1 Weleri Tahun Ajaran 2012/2013 Oleh: Romdonah*)
}

\begin{abstract}
Abstrak:
Berdasar kurikulum Mulok bahasa Jawa, melalui pembelajaran bahasa Jawa diharapkan siswa terampil mengemukakan gagasan dan perasaannya secara lisan maupun tulis melalui pengembangan keterampilan imajinatif. Salah satu keterampilan imajinatif tersebut yakni menulis puisi berbahasa Jawa (geguritan). Kenyataan di lapangan menunjukkan siswa kelas IXA SMP Negeri 1 Weleri pada tahun ajaran 2012/2013 banyak yang mengalami kesulitan dalam menulis geguritan. Kesulitan tersebut berupa pengembangan imajinasi terhadap peristiwa yang dialami dan dilihatnya. Kondisi awal menunjukkan dari 27 siswa, baru 14 siswa yang dapat menulis geguritan dengan baik. Ini berarti ketuntasan belajar belum tercapai karena ketuntasan baru $51,83 \%$, sedangkan ketuntasan belajar dikatakan tercapai jika sebesar $85 \%$.

Rendahnya keterampilan siswa dalam menulis geguritan dikarenakan kurangnya pemahaman siswa tentang geguritan dan cara penulisannya serta guru tidak menggunakan media dan teknik pembelajaran yang dapat menumbuhkan kreativitas dan mempermudah pengimajinasian peristiwa.

Berdasar hal tersebut, dalam penelitian ini dikaji dua permasalahan, yakni: (1) berapa besar peningkatan keterampilan menulis puisi berbahasa Jawa (geguritan) siswa kelas IXA SMP Negeri 1 Weleri tahun ajaran 2013/2013 dengan menggunakan media VCD peristiwa menyentuh hati dan teknik tangpitu (tangkap, pikir, tulis)? dan (2) bagaimana perubahan perilaku belajar siswa kelas IXA SMP Negeri 1 Weleri tahun ajaran 2013/2013 setelah digunakan media VCD peristiwa menyentuh hati dan teknik tangpitu (tangkap, pikir, tulis)?

Sesuai dengan permasalahan, penelitian ini bertujuan menentukan besaran peningkatan keterampilan menulis puisi berbahasa Jawa (geguritan) siswa kelas IXA SMP Negeri 1 Weleri tahun ajaran 2013/2013 dengan menggunakan media VCD peristiwa yang menyentuh hati dan teknik tangpitu (tangkap, pikir, tulis) dan mendeskripsi perubahan perilaku belajar siswa kelas IXA SMP Negeri 1 Weleri tahun ajaran 2013/2013 setelah digunakan media VCD peristiwa menyentuh hati dan teknik tangpitu (tangkap, pikir, tulis).

Dari analisis data secara kuantitatif menunjukkan adanya peningkatan keterampilan menulis geguritan dengan menggunakan media VCD peristiwa yang menyentuh hati dan teknik tangpitu (tangkap, pikir, tulis). Pada tahap pra-siklus nilai rata-rata hasil tes mencapai 77,56. Hal tersebut meningkat sebesar $63,95 \%$ pada siklus I dengan nilai rata-rata sebesar 82,52. Kekurangan pada siklus I adalah kurang maksimalnya siswa dalam menghayati isi. Pada siklus II hasil tersebut meningkat sebesar 51,99\% dengan nilai rata-rata sebesar 86,81. Dari analisis data secara kualitatif diperoleh hasil sebagian besar siswa tertarik dengan teknik dan media yang digunakan dalam penelitian ini.

Berdasar hasil penelitian, peneliti menyarankan guru dapat menggunakan menggunakan media VCD peristiwa yang menyentuh hati dan teknik tangpitu (tangkap, pikir, tulis) dalam pembelajaran menulis geguritan agar mampu meningkatkan keterampilan siswa dalam menulis geguritan.
\end{abstract}

Kata kunci: keterampilan menulis, geguritan, media VCD peristiwa menyentuh hati dan teknik tangpitu (tangkap, pikir, tulis) 


\section{PENDAHULUAN}

Rumusan kompetensi dasar dalam kurikulum bahasa Jawa kelas IX, dinyatakan secara eksplisit bahwa siswa harus mampu menulis susastra sederhana misalnya geguritan. Melalui pembelajaran bahasa Jawa, siswa diharapkan terampil mengemukakan gagasan dan perasaannya secara lisan maupun tulis, dan mengembangkan keterampilan imajinatif yang ada dalam dirinya. Salah satu keterampilan imajinatif yang dapat dikembangkan yakni menulis puisi berbahasa Jawa (geguritan).

Kenyataan di lapangan menunjukkan siswa kelas IXA SMP Negeri 1 Weleri Kendal pada tahun ajaran 2012/2013 banyak mengalami kesulitan dalam menulis geguritan. Kesulitan tersebut berupa pengembangan imajinasi terhadap peristiwa yang dialami dan dilihatnya. Berdasar KKM yang telah ditetapkan sebesar 78,00, persentase ketuntasan belajar siswa belum tercapai, karena dari 27 siswa baru 14 (51,83\%) siswa yang dapat menulis geguritan dengan baik. Adapun ketuntasan belajar dikatakan tercapai jika mencapai $85 \%$.

Dari hasil identifikasi masalah, rendahnya keterampilan siswa dalam menulis geguritan karena kurangnya pemahaman siswa tentang geguritan dan cara penulisannya serta guru tidak menggunakan media dan teknik pembelajaran yang dapat menumbuhkan kreativitas pengimajinasian peristiwa. Oleh karena itu, dalam penelitian ini dilakukan tindakan berupa penggunaan media VCD peristiwa menyentuh hati dan teknik tangpitu (tangkap, pikir, tulis) dalam pembelajaran menulis geguritan.

Dari latar belakang masalah tersebut, maka dalam penelitian ini dikaji dua permasalahan, yakni: (1) berapa besar peningkatan keterampilan menulis puisi berbahasa Jawa (geguritan) siswa kelas IXA SMP Negeri 1 Weleri tahun ajaran 2013/2013 dengan menggunakan media VCD peristiwa menyentuh hati dan teknik tangpitu (tangkap, pikir, tulis)? dan (2) bagaimana perubahan perilaku belajar siswa kelas IXA SMP Negeri 1 Weleri tahun ajaran 2013/2013 setelah digunakan media VCD peristiwa menyentuh hati dan teknik tangpitu (tangkap, pitu). Sesuai rumusan masalah, penelitian ini bertujuan: menentukan besaran peningkatan keterampilan menulis puisi berbahasa Jawa (geguritan) siswa kelas IXA SMP Negeri 1 Weleri tahun ajaran 2013/2013 dengan menggunakan media VCD peristiwa yang menyentuh hati dan teknik tangpitu (tangkap, pikir, tulis)? dan mendeskripsi perubahan perilaku belajar siswa kelas IXA SMP Negeri 1 Weleri tahun 
ajaran 2013/2013 setelah digunakan media VCD peristiwa menyentuh hati dan teknik tangpitu (tangkap, pikir, tulis).

Hasil penelitian ini diharapkan dapat memberi manfaat praktis, yakni dengan ditemukan media dan teknik baru, maka dapat meningkatkan keterampilan siswa dalam menulis geguritan.

\section{LANDASAN TEORI}

\section{Keterampilan Menulis Puisi Berbahasa Jawa (Geguritan)}

Dalam Kamus Besar Bahasa Indonesia, keterampilan berarti kesanggupan atau kecakapan untuk melakukan sesuatu. Menulis menurut Suparno (2008) adalah penyampaian pesan (ide, gagasan, perasaan, atau informasi) secara tertulis kepada pihak lain (pembaca). Menurut Waluyo (2002: 1) puisi adalah karya sastra dengan bahasa yang dipadatkan, dipersingkat, dan diberi irama dengan bunyi yang padu dan pemilihan katakata kias (imajinatif).

Djojosuroto (2005: 15 ) menyatakan struktur fisik puisi dibangun oleh diksi, bahasa kias/gaya bahasa (figurative language), pencitraan (imagery), dan persajakan. Struktur batin dibangun oleh pokok pikiran (subject matter), tema, nada (tone), suasana (atmosphere), dan amanat (message).

Geguritan dibedakan menjadi dua yakni geguritan tradisional dan geguritan modern. Menurut Darnawi (1963: 53) aturan geguritan tradisional yakni: jumlah gatra guritan itu tidak tetap, setiap gatra berisi 8 wanda, bunyi pada akhir gatra bersajak sama, dan setiap geguritan dimulai dengan kata "Sun nggegurit" (aku mengarang/membaca geguritan). Adapun geguritan modern adalah puisi (bebas) yang ditulis penyair Jawa dalam bahasa Jawa.

\section{Media VCD Peristiwa Menyentuh Hati}

Anitah (2010:4) memberi definisi media pembelajaran adalah setiap orang, bahan, alat, atau peristiwa yang dapat menciptakan kondisi yang memungkinkan pembelajar dapat menciptakan pengetahuan, keterampilan, dan sikap. Jenis media ada tiga yakni media yang didengar (auditory), media yang dilihat (visual), serta media yang didengarkan dan dilihat (audio-visual). Media visual disebut media pandang, karena seseorang dapat menghayati media tersebut melalui penglihatannya. Media tersebut dapat dibagi menjadi dua, yakni media visual yang dapat diproyeksikan dan media visual yang tidak dapat diproyeksikan. Pemilihan VCD peristiwa menyentuh hati dalam penelitian ini sebagai 
sarana peningkatan olah rasa hasil pandangan dan pemahaman, serta penanaman nilai karakter yang dituangkan dalam bentuk tulisan yang disebut geguritan.

\section{Teknik Tangpitu (Tangkap, Pikir, Tulis)}

Teknik menurut Kamus Besar Bahasa Indonesia adalah pengetahuan dan kepandaian, cara, atau metode mengerjakan membuat sesuatu. Teknik Tangpitu (tangkap, pikir, tulis) sebenarnya merupakan temuan teknik baru yang diciptakan dalam penelitian ini. Langkah teknik Tangpitu (tangkap, pikir, tulis) meliputi tiga langkah. Langkah pertama yakni pemutaran VCD video klip lagu "Bunda" dengan durasi waktu 15 menit pada siklus I dan VCD peristiwa proses kelahiran janin dan perjuangan ibu untuk anaknya pada siklus II. Melalui tayangan tersebut diharapkan siswa mampu menangkap isinya yang untuk selanjutnya diberi istilah tangkap. Pada langkah kedua siswa diajak untuk berlatih khayalan mental (pikir) dengan cara: siswa untuk menutup matanya, melakukan relaksasi untuk memperjelas pikiran-pikiran yang muncul setelah mereka melihat tayang video, berkhayal berdasarkan pikiran yang muncul dalam waktu lima menit, dan membuka mata serta melukiskan khayalan dalam bentuk tulisan melalui pertanyaan-pertanyaan yang mendorong panca indera, seperti: siapa yang kamu lihat, apa yang sedang mereka alami, bagaimana seandainya itu terjadi pada dirimu, apa yang akan kamu lakukan, dan lain sebagainya. Pada langkah ketiga guru mengajak siswa untuk menyimpulkan khayalan mereka masing-masing dalam bentuk tulisan yang berbentuk geguritan yang untuk selanjutnya diberi istilah teknik tulis. Sebelum siswa memulai menulis, guru harus menjelaskan tata cara menulis geguritan.

\section{Penelitian yang Relevan}

Penelitian tentang pembelajaran menulis puisi berbahasa Jawa (geguritan) telah dilakukan sebagai dasar bahan kajian pustaka dalam penelitian ini adalah penelitian yang dilakukan oleh Rahmayantis yang berjudul "Peningkatan Kemampuan Menulis Geguritan Siswa Kelas VIII SMPN 1 Campurdarat Tahun Ajaran 2010/2011 dengan Menggunakan Metode Experiential Learning”. Penelitian tersebut dilatarbelakangi adanya hambatan internal pada diri siswa dalam menulis geguritan. Adapun hambatannya siswa sulit menyesuaikan judul dengan isi geguritan, pemilihan diksi, penggunaan penginderaan, dan bahasa figuratif dalam penulisan geguritan. Cara pemecahan masalah dengan menggunakan dengan menggunakan metode experiential learning. Rahmayantis 
menyimpulkan adanya peningkatan pada kemampuan menulis geguritan siswa kelas VIII SMPN 1 Campurdarat setelah menggunakan metode experiential learning.

Berbeda dengan Rahmayantis, Smaradewanimas melakukan penelitian dengan judul "Peningkatan Keterampilan Menulis Geguritan melalui Teknik Kata Kunci pada Siswa Kelas X-8 SMA Negeri 2 Brebes”. Penelitian tersebut dilatarbelakangi kesulitan siswa SMA Negeri 2 Brebes dalam memilih kosa kata bahasa Jawa yang tepat dalam pembelajaran menulis geguritan. Salah satu usaha yang dapat dilakukan melalui teknik kata kunci. Berdasarkan hasil tes terjadi peningkatan keterampilan menulis geguritan dari kondisi awal yang semula rata-ratanya 60,8 dengan kategori cukup, pada siklus I rata-rata menulis geguritan siswa meningkat menjadi 66,04 masih dalam kategori cukup. Siklus II nilai rata-rata menulis geguritan siswa meningkat menjadi 73,11 dengan kategori baik.

Persamaan penelitian Rahmayantis dan Smaradewanimas dengan penelitian ini dalam hal variabel input berupa bahan pembelajaran, yakni menulis geguritan. Adapun perbedaan kedua penelitian dengan penelitian yang dilakukan penulis pada variabel kedua yakni adanya tindakan penggunaan teknik tangpitu (tangkap, pikir, tulis) sebagai pengembangan penelitian yang telah dilakukan pada penelitian sebelumnya.

\section{Kerangka Berpikir}

Media VCD peristiwa menyentuh hati menampilkan sebuah visualisasi yang dapat memberi gambaran konkret peristiwa nyata dan dapat dijadikan topik dan inspirasi siswa dalam menulis geguritan. Melalui teknik Tangpitu (tangkap, pikir, tulis) semakin mempermudah siswa dalam mengapresiasi dan dan mewujukan imajinasi dalam bentuk geguritan.

\section{Hipotesis Tindakan}

Dengan penggunaan media VCD peristiwa menyentuh hati dan teknik tangpitu (tangkap, pikir, tulis) dalam pembelajaran menulis geguritan, keterampilan menulis geguritan siswa kelas IXA SMP Negeri 1 Weleri tahun ajaran 2012/2013 dapat ditingkatkan.

\section{METODE PENELITIAN}

Desain penelitian yang digunakan adalah desain penelitian tindakan kelas yang memusatkan pada permasalahan yang spesifik dan kontekstual. Penelitian ini didesain dalam dua siklus. Tiap siklus terdiri atas empat tahap, yaitu perencanaan, tindakan, pengamatan/observasi, dan refleksi (Aqib 2009:7). Perencanaan merupakan rencana kegiatan yang meliputi keseluruhan aspek yang berhubungan dengan penelitian tindakan 
kelas dan rancangan dari siklus per siklus yang berkaitan dengan teknik, media, materi pembelajaran, dan alokasi waktu. Observasi dilakukan dengan mencatat hal yang yang terjadi di kelas. Refleksi dilakukan setelah proses pembelajaran berlangsung dan dilaksanakan setelah perlakuan tindakan dan berdasar hasil observasi.

Sumber data dalam penelitian ini adalah siswa kelas IXA SMP Negeri 1 Weleri tahun ajaran 2012/2013 sejumlah 27 siswa. Adapun subjek penelitiannya adalah media VCD peristiwa menyentuh hati dan teknik tangpitu (tangkap, pikir, tulis) dalam pembelajaran menulis geguritan.

\section{Variabel Penelitian}

Variabel dalam penelitian ini ada dua macam, yakni variabel keterampilan menulis puisi berbahasa Jawa (geguritan) serta variabel penggunaan media VCD peristiwa menyentuh hati dan teknik Tangpitu (tangkap, pikir, tulis).

\section{Instrumen Penelitian}

Instrumen yang digunakan ada dua yakni instrumen tes dan nontes. Instrumen tes berupa tes subjektif menulis geguritan dengan memperhatikan aspek-aspek penilaian menulis geguritan dan dinilai berdasar rubrik dan pedoman penilaian ini dapat dipaparkan pada tabel berikut ini.

Tabel 1: Rubrik Penilaian dan Pedoman Penilaian Menulis Geguritan

\begin{tabular}{|l|l|c|c|c|c|c|c|c|c|c|}
\hline No. & Aspek Penilaian & \multicolumn{3}{|c|}{ Skala Nilai } & \multirow{2}{*}{ Bobot } & Skor & Rentang Nilai & Kategori \\
\cline { 3 - 8 } & & $\mathbf{1}$ & $\mathbf{2}$ & $\mathbf{3}$ & $\mathbf{4}$ & $\mathbf{5}$ & & & & \\
\hline 1 & Kesesuaian isi & & & & & & 6 & 30 & $90-100$ & Sangat Baik \\
& dengan tema & & & & & & 4 & 20 & $80-89$ & Baik \\
2 & Diksi & & & & & & 4 & 20 & $70-79$ & Cukup \\
3 & Rima & & & & & & 4 & 20 & $60-69$ & Kurang \\
4 & Tipografi & & & & & & 2 & 10 & $</=59$ & Sangat kurang \\
5 & Amanat & & & & & & & & \\
\hline
\end{tabular}

Adapun instrumen non-tes berupa lembar observasi, lembar wawancara, catatan harian, dan dokumentasi. Instrumen non-tes digunakan untuk mengamati keadaan, respon, sikap, dan keaktifan siswa selama mengikuti proses pembelajaran berlangsung.

\section{Teknik Pengambilan Data}

Teknik pengumpulan data dalam penelitian ini ada dua, yakni: teknik tes (portofolio) dan teknik non-tes. Teknik portofolio untuk mendapatkan skor dari kumpulan hasil karya geguritan yang dihasilkan siswa, sedangkan teknik non-tes untuk mengetahui perubahan perilaku belajar siswa setelah digunakan media VCD peristiwa menyentuh hati dan Teknik Tangpitu (tangkap, pikir, tulis) dalam pembelajaran menulis puisi berbahasa Jawa (geguritan). 


\section{Teknik Analisis Data}

Teknik analisis data dilakukan secara kuantitaif dan kualitatif. Hasil portofolio dianalisis secara kuantitatif atau deskriptif dihitung secara persentase dengan langkah dengan rumus:

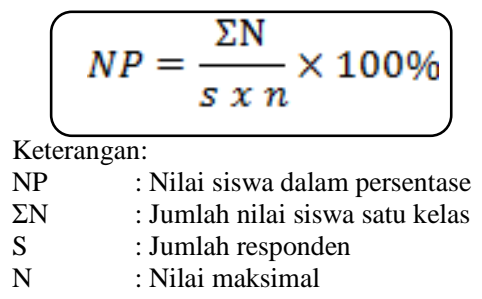

Hasil perhitungan keterampilan siswa dalam menulis geguritan dari masingmasing siklus ini dibandingkan agar diperoleh gambaran persentase peningkatan. Analisis kualitatif dimaksudkan untuk menganalisis data non-tes yang diperoleh dari siswa.

\section{Indikator Kinerja}

Indikator kinerja penelitian ini mengacu kepada Kriteria Ketuntasan Minimal (KKM) yang telah ditetapkan yakni 78,00. Siklus penelitian ini dinyatakan berhasil bila $85 \%$ siswa telah mencapai nilai minimal 78,00 .

\section{HASIL PENELITIAN DAN PEMBAHASAN}

\section{Hasil Penelitian}

\section{Hasil Kondisi Awal (Pra-siklus)}

Hasil penjajakan (pra-siklus) menunjukkan bahwa dari 27 orang siswa kelas IXA, baru 14 orang siswa $(51,85 \%)$ yang dapat mencapai nilai di atas KKM. Sebanyak 13 orang siswa $(48,15 \%)$ belum dapat mencapai nilai sesuai dengan KKM. Adapun nilai rataratanya hanya sebesar 77,56 .

Hasil nontes berupa observasi perilaku siswa menunjukkan siswa kurang bersemangat. Hal ini dapat ditunjukkan dalam dokumentasi foto siswa selama pembelajaran yang terlihat tidak antusias, dan ogah-ogahan yang dapat diwakili pada gambar berikut ini.
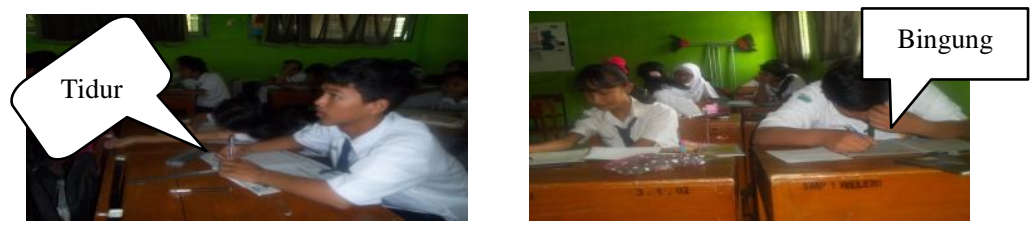

Gb. 1: Pembelajaran Tahap Kondisi Awal/Prasiklus

\section{Hasil Penelitian Siklus I}

*) Guru Bahasa Jawa SMP Negeri 1 Weleri Kendal 
Hasil penelitian siklus I ini meliputi portofolio geguritan dan nontes. Hasil portofolio berupa hasil menulis geguritan siswa kelas IXA SMP Negeri 1 Weleri setelah mengikuti pembelajaran menulis geguritan melalui media VCD menyentuh hati dan teknik tangpitu (tangkap, pikir, tulis) dengan memperhatikan aspek-aspek penilaian menulis geguritan. Hasil portofolio siklus I menunjukkan keterampilan siswa kelas IXA SMP Negeri 1 Weleri dalam menulis geguritan setelah digunakan media VCD peristiwa menyentuh hati dan Teknik Tangpitu (tangkap, pikir, tulis) dengn kategori baik dan dapat dilihat pada tabel berikut ini.

Tabel 2: Hasil Menulis Puisi Geguritan Siklus I

\begin{tabular}{|c|c|c|c|c|c|c|}
\hline No. & $\begin{array}{c}\text { Rentang } \\
\text { Nilai }\end{array}$ & Kategori & Frekuensi & $\begin{array}{l}\text { Bobot } \\
\text { Skor }\end{array}$ & $\begin{array}{c}\text { Persentase } \\
(\%)\end{array}$ & $\begin{array}{c}\text { Nilai } \\
\text { Rata-Rata } \\
\end{array}$ \\
\hline 1 & $90-100$ & Sangat Baik & 4 & 368 & 14,82 & \multirow{5}{*}{$\begin{array}{l}2228: 27 \\
=82,52 \\
\text { (Kategori Baik) }\end{array}$} \\
\hline 2 & $80-89$ & Baik & 15 & 1256 & 55,55 & \\
\hline 3 & $70-79$ & Cukup & 8 & 604 & 29,63 & \\
\hline 4 & $60-69$ & Kurang & 0 & 0 & 0,00 & \\
\hline 5 & $</=59$ & Sangat Kurang & 0 & 0 & 0,00 & \\
\hline \multicolumn{3}{|c|}{ Jumlah } & 27 & 2228 & 100 & \\
\hline
\end{tabular}

Pada pembelajaran menulis geguritan ini, jumlah siswa yang memperoleh nilai 90100 dengan kategori sangat baik dicapai oleh 4 siswa atau sebesar 14,82\%. Siswa yang memperoleh nilai 80-89 dengan kategori baik dicapai oleh 15 siswa atau 55,55\%. Siswa yang memperoleh nilai 70-79 dengan kategori cukup dicapai oleh 8 siswa atau sebesar 29,63\%. Siswa yang memperoleh nilai 60-69 dan $</=59$ dengan kategori kurang dan sangat kurang ada 0 siswa atau sebesar $0,00 \%$ dari jumlah keseluruhan siswa. Untuk lebih jelasnya, persentase hasil siklus I secara keseluruhan dapat dilihat pada diagram berikut ini.

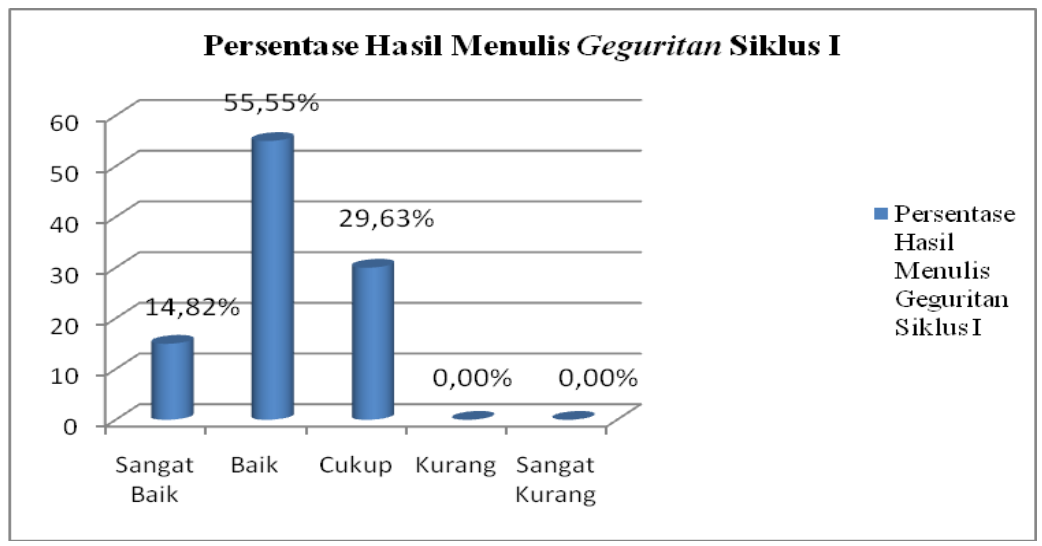

\section{Diagram 1: Persentase Hasil Menulis Geguritan Siklus I}

Hasil nontes berupa observasi pada siklus I dilakukan ternyata tidak semua siswa menunjukkan perilaku positif. Masih ada siswa yang menunjukkan perilaku negatif yang 
kurang semangat dan kurang antusias dan tidak memperhatikan ketika guru menerangkan. Masih ada siswa yang merespon negatif terhadap media VCD yang digunakan peniliti dan pasif selama proses pembelajaran.

Dari catatan harian guru dan siswa pada siklus I, sebagian besar siswa belum aktif. Mereka lebih banyak pasif dan hanya mendengarkan penjelasan guru. Siswa yang aktif hanya 55,55\% yang mau bertanya kepada guru. Tingkah laku siswa selama proses pembelajaran, sebagian besar sudah menunjukkan sikap perhatian dan ketertiban serta dapat dikategorikan cukup baik. Namun demikian, masih ada siswa yang membuat keusilan di antara teman-temannya.

Wawancara pada siklus I ini dilaksanakan di luar jam pelajaran kepada siswa yang mendapat nilai tertinggi (T), sedang (S), dan rendah (R). Siswa (T dan S) berminat dengan alasan, melalui menulis geguritan dapat mengungkapkan isi hati dan menumbuhkan kreativitas. Siswa (R) kurang berminat dengan alasan merasa tidak berbakat menulis geguritan.

Penggunaan instrumen dokumentasi meliputi pengambilan gambar (foto) dan video dengan tujuan untuk memperoleh rekaman aktivitas siswa selama mengikuti proses pembelajaran dan memperjelas data lain yang dideskripsi melalui kalimat dan angka. Dokumentasi foto diwakili gambar berikut ini.
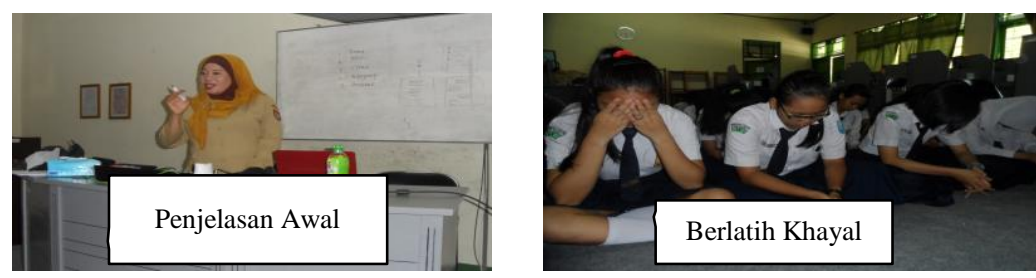

Gb. 2: Pembelajaran Siklus I

Refleksi Siklus I dilakukan dengan cara membandingkan hasil tes siklus I dengan nilai rata-rata sebesar 82,52 yang mengalami peningkatan dibanding kondisi awal yang mencapai nilai rata-rata 77,56. Keberhasilan pembelajaran pada siklus ini, disebabkan siswa menjadi senang dalam menulis geguritan dan tidak terlalu kesulitan dalam menulis geguritan, serta kreativitas, semangat, dan antusias siswa lebih meningkat

Pada siklus I masih ada kelemahan yang ditunjukkan dengan masih ada siswa yang merasa kesulitan dan membutuhkan waktu lama untuk menulis geguritan.

\section{Hasil Penelitian Siklus II}

*) Guru Bahasa Jawa SMP Negeri 1 Weleri Kendal 
Hasil penelitian siklus II ini diperoleh melalui fortofolio geguritan dan nontes. Hasil portofolio siklus II menunjukkan keterampilan siswa menulis geguritan setelah digunakan media VCD peristiwa menyentuh hati dan teknik Tangpitu (tangkap, pikir, tulis) mengalami peningkatan. Hal ini dapat dilihat pada tabel berikut.

Tabel 3: Hasil Menulis Geguritan Siklus II

\begin{tabular}{|c|c|c|c|c|c|c|}
\hline No. & $\begin{array}{c}\text { Rentang } \\
\text { Nilai }\end{array}$ & Kategori & Frekuensi & $\begin{array}{l}\text { Bobot } \\
\text { Skor }\end{array}$ & $\begin{array}{c}\text { Persentase } \\
(\%)\end{array}$ & $\begin{array}{c}\text { Nilai } \\
\text { Rata-Rata }\end{array}$ \\
\hline 1 & $90-100$ & Sangat Baik & 5 & 476 & 18,52 & \multirow{5}{*}{$\begin{array}{l}2344: 27 \\
=86,81 \\
\text { (Kategori Baik ) }\end{array}$} \\
\hline 2 & $80-89$ & Baik & 20 & 1716 & 74,07 & \\
\hline 3 & $70-79$ & Cukup & 2 & 152 & 7,41 & \\
\hline 4 & $60-69$ & Kurang & 0 & 0 & 0,00 & \\
\hline 5 & $</=59$ & Sangat Kurang & 0 & 0 & 0,00 & \\
\hline \multicolumn{3}{|c|}{ Jumlah } & 27 & 2344 & 100 & \\
\hline
\end{tabular}

Tabel tersebut menunjukkan rata-rata skor yang dicapai sebesar $86,81 \mathrm{n}$ dan termasuk kategori baik. Hasil telah melampaui standar minimal klasikal yang dibutuhkan dalam penelitian ini. Persentase hasil siklus II secara keseluruhan dapat dilihat pada diagram berikut ini.

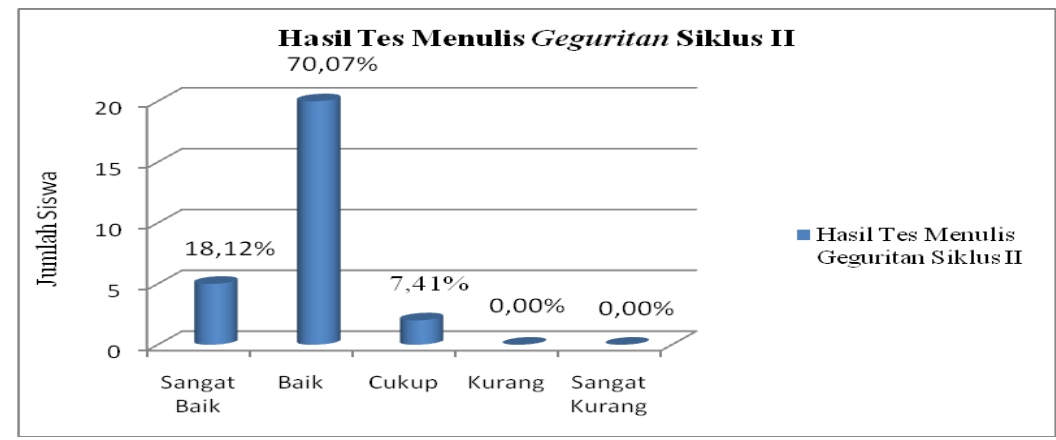

Diagram 2: Persentase Hasil Menulis Geguritan) Siklus II

Hasil nontes siklus II pada penelitian ini diperoleh dari observasi, catatan harian, wawancara, dan dokumentasi. Dari hasil observasi pada siklus II diketahui perilaku siswa lebih ke arah positif bila dibandingkan dengan perilaku siswa pada siklus I. Namun masih ada siswa yang menunjukkan perilaku negatif. yakni kurang semangat atau kurang antusias mengikuti pembelajaran, tidak memperhatikan dengan baik ketika guru menjelaskan, merespon negatif terhadap media dan teknik guru (peneliti), tidak aktif selama pembelajaran, serta engerjakan tugas sambil mengerjakan tugas yang lain.

Dari catatan harian guru selama proses pembelajaran pada siklus II, keaktifan siswa meningkat dibandingkan pada siklus I. Tingkah laku siswa selama pembelajaran sebagian besar sudah menunjukkan sikap perhatian dan ketertiban serta dapat dikatakan 
lebih baik dibandingkan dengan siklus I. Namun, masih ada siswa yang melakukan keusilan kecil dan tidak mengganggu jalannya proses pembelajaran.

Respon siswa terhadap pembelajaran, sejak awal mereka semangat dan antusias. Namun, berdasarkan pengamatan guru, masih beberapa siswa yang tidak semangat. Meskipun demikian, hal itu tidak mempengaruhi teman yang lain. Suasana pembelajaran pada siklus II sudah lebih tertib. Respon siswa terhadap media VCD yang digunakan peneliti, sebagian besar sangat antusias seperti pada siklus I.

Dari catatan harian siswa diperoleh hasil mereka merasa senang ketika mengikuti pembelajaran dan akhirnya mereka dapat menulis namun masih ada siswa yang merasa kesulitan ketika memilih kata-kata sesuai tema. Rata-rata siswa menanggapi media VCD sangat menarik, meskipun masih ada siswa menanggapai media VCD masih membingungkan.

Wawancara pada siklus II ini dilaksanakan di luar jam pelajaran. Wawancara dilakukan kepada siswa yang mendapat nilai tertinggi (T), sedang (S), dan rendah (R). Siswa (T) berminat dengan alasan, melalui menulis geguritan dapat mengungkapkan isi hati dan menumbuhkan kreativitas. Siswa (S) Sangat berminat dengan sebelumnya sudah menyukai geguritan meski sebatas hanya membacanya. Siswa (R) kurang berminat dengan alasan merasa tidak berbakat menulis geguritan.

Dokumentasi dilakukan pada saat pembelajaran yang dapat diwakili dokumentasi foto berikut ini.
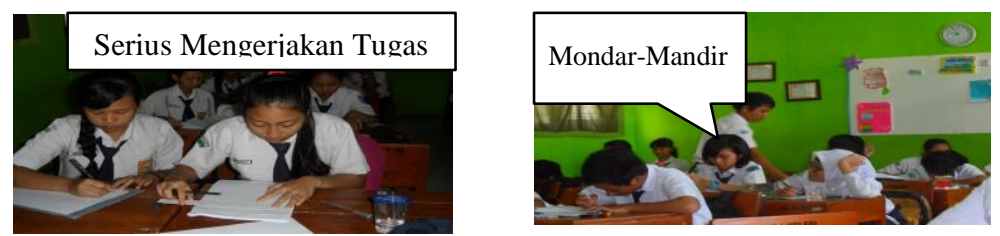

Gb. 8: Pembelajaran Siklus II

Hasil refleksi keterampilan menulis geguritan pada siklus II menunjukkan telah mengalami peningkatan dari siklus I dan sudah mencapai kategori baik. Siswa dapat menulis geguritan sesuai dengan kriteria penulisan dan senang terhadap media dan teknik yang digunakan peneliti. Selain itu, telah terjadi perubahan perilaku siswa. Banyak siswa yang aktif dalam kegiatan pembelajaran, meskipun masih ada beberapa siswa yang kurang antusias.

\section{Pembahasan}


Pembahasan hasil penelitian ditujukan untuk menemukan jawaban atas permasalahan yang telah dirumuskan dalam penelitian. Berikut dipaparkan satu per satu permasalahan tersebut.

\section{1) Peningkatan Keterampilan Menulis Geguritan}

Hasil portofolio keterampilan menulis geguritan mengalami peningkatan pada setiap tahapan siklusnya, dari mulai tahapan prasiklus, siklus I, dan siklus II. Kenyataan tersebut dapat dilihat pada tabel berikut ini.

Tabel 4: Peningkatan Nilai Rata-Rata Hasil Menulis Geguritan Tahap Prasiklus, Siklus I, dan Siklus I

\begin{tabular}{|l|l|l|l|l|l|l|l|l|l|l|l|l|}
\hline Tahap & \multicolumn{1}{|c|}{$\begin{array}{c}\text { Nilai } \\
\text { Rata-Rata }\end{array}$} & \multicolumn{5}{|c|}{ Distribusi Frekuensi } & \multicolumn{5}{|c|}{ Distribusi Persentase } \\
\cline { 3 - 16 } & & SB & B & C & K & SK & Jml & SB & B & C & K & SK \\
\hline Prasiklus & 77,56 & 2 & 11 & 11 & 1 & 2 & 27 & 7,41 & 40,74 & 40,74 & 3,70 & 7,41 \\
\hline Siklus I & 82,52 & 4 & 15 & 8 & 0 & 0 & 27 & 14,82 & 55,56 & 29,63 & 0 & 0 \\
\hline Siklus II & 86,81 & 5 & 20 & 2 & 0 & 0 & 27 & 18,52 & 74,07 & 7,41 & 0 & 0 \\
\hline
\end{tabular}

Dengan tabel tersebut, dapat dihitung peningkatan nilai rata-rata dari tahap prasiklus, siklus I, dan siklus II. Hasil pada siklus I meningkat sebesar 4,96 atau 6,40\% dari nilai rata-rata tahap pra-siklus sebesar 77,56. Hasil siklus II meningkat sebesar 4,29 atau $5,12 \%$ dari siklus I yang memiliki rata-rata sebesar 82,52 dan siklus II meningkat sebesar 9,25 atau $11,93 \%$ dari nilai rata-rata tahap pra-siklus sebesar 77,56.

Nilai rata-rata siswa pada siklus I menunjukkan peningkatan dibanding tahap pra-siklus, yakni sebesar 82,52. Pada tahap siklus I termasuk dalam kategori baik dan sudah mencapai nilai KKM. Namun hal tersebut tetap diupayakan adanya tindakan lebih lanjut pada siklus II.

Nilai rata-rata pada siklus II mengalami peningkatan yakni sebesar 86,81 dibandingkan pada siklus I yang hanya sebesar 82, 52 . Hasil siklus II termasuk kategori baik dengan nilai rata-rata di atas KKM. Dengan demikian, tidak perlu dilakukan tindakan siklus III. Peningkatan nilai rata-rata dapat dilihat dari diagram berikut ini. 


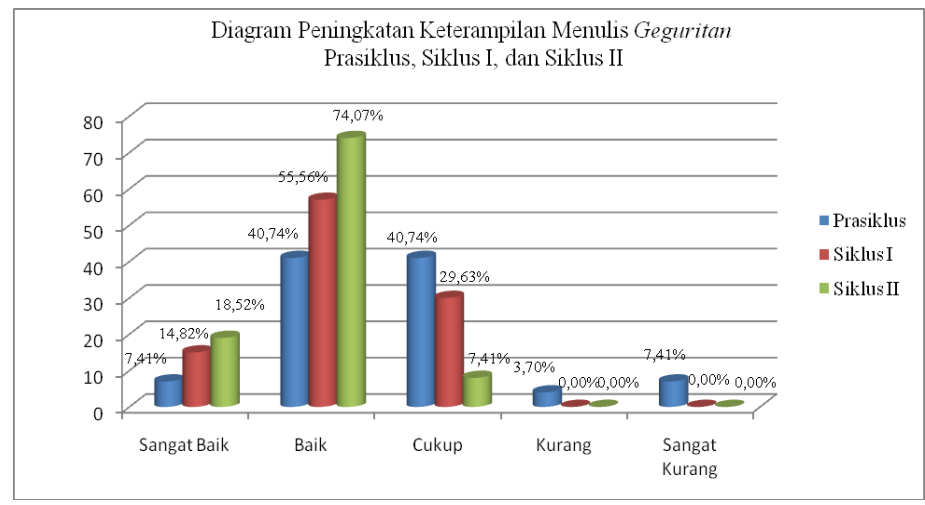

Diagram 3: Peningkatan Keterampilan Menulis Geguritan Tahap Prasiklus, Siklus I, dan Siklus II

\section{2) Perubahan Perilaku Belajar Siswa Kelas IXA SMP Negeri 1 Weleri}

Berdasarkan hasil observasi pada siklus I dan siklus II dapat diketahui setiap aspek yang terdapat dalam observasi mengalami peningkatan dari siklus I ke siklus II. Catatan harian siswa dan guru menunjukkan siswa merasa senang dengan pembelajaran menulis geguritan melalui media VCD peristiwa menyentuh hati dan teknik Tangpitu (tangkap, pikir, tulis). Dari hasil wawancara siswa merasa senang dengan media dan teknik yang digunakan peneliti karena dapat membantu siswa dalam mengungkapkan ide dan menambah kreativitas dalam menulis geguritan.

Berdasarkan hasil siklus I dan siklus II dapat disimpulkan bahwa pembelajaran menulis geguritan siklus I melalui media VCD peristiwa menyentuh hati dan teknik tangpitu (tangkap, pikir, tulis) siswa kelas IXA SMP Negeri 1 Weleri mampu memberi perubahan perilaku siswa ke arah yang lebih baik.

\section{SIMPULAN DAN SARAN}

\section{Simpulan}

Berdasarkan tujuan penelitian, rumusan masalah, dan pembahasan hasil penelitian, setelah dilakukan tindakan berupa penggunaan media VCD peristiwa menyentuh hati dan teknik Tangpitu (tangkap, pikir, tulis) dalam pembelajaran dapat disimpulkan sebagai berikut.

1) Terjadi peningkatan keterampilan siswa dalam menulis geguritan.

Persentase ketuntasan belajar yang pada kondisi awal 58,33\% naik menjadi 70,37 \% pada siklus I dan meningkat menjadi 92,59\% pada siklus II. Begitu pula nilai rata-rata yang dicapai siswa mengalami perubahan. Pada kondisi awal rata-rata yang dicapai sebesar 77,56 naik menjadi 82,52 pada siklus I, dan meningkat menjadi 86,81 pada siklus II.

*) Guru Bahasa Jawa SMP Negeri 1 Weleri Kendal 
2) Pembelajaran menulis geguritan melalui media VCD peristiwa menyentuh hati dan teknik tangpitu (tangkap, pikir, tulis) mampu memberi perubahan perilaku siswa siswa kelas IXA SMP Negeri 1 Weleri ke arah yang lebih baik.

\section{B. Saran}

1) Penggunaan media VCD peristiwa menyentuh hati dan teknik Tangpitu (tangkap, pikir, tulis) hendaknya dapat digunakan oleh guru dalam pembelajaran menulis geguritan agar dapat meningkatkan keterampilan siswa dalam menulis geguritan.

2) Penggunaan media VCD peristiwa menyentuh hati dan teknik Tangpitu (tangkap, pikir, tulis) perlu dikembangkan lagi lebih inovatif oleh peneliti lain. 


\section{DAFTAR PUSTAKA}

Anitah, Sri. 2009. Media Pembelajaran. Surakarta: Yuma Pustaka.

Aqib, Zaenal. 2009. Penelitian Tindakan Kelas untuk Guru SMP, SMA, SMK. Bandung: CV. Yrama Widya.

Darnawi. 1963. Pengantar Puisi Djawa. Jakarta: Balai Pustaka.

Djoyosuroto, Kinayati. 2005. Pusi Pendekatan dan Pembelajaran. Jakarta: Nuansa.

Rahmayantis. 2011. Peningkatan Kemampuan Menulis Geguritan Siswa Kelas VIII SMPN 1 Campurdarat Tahun Ajaran 2010/2011 dengan Menggunakan Metode Experiential Learning. Skripsi. Unnes. Tidak dipublikasikan.

Smaradewanimas, Margeadetari. 2009. Peningkatan Keterampilan Menulis Puisi Melalui Teknik Kata Kunci pada Siswa Kelas X-8 SMA N 2 Brebes. Skripsi. Unnes. Tidak dipublikasikan.

Shofa, Faila. 2010. Peningkatan Keterampilan Menulis Puisi melaui Strategi Pikir Plus dengan Media Surat Kabar Siswa Kelas X-4 Nahdlatul Ulama Muslimun Undaan Kudus Tahun Ajaran 2009/2010. Skripsi. Unnes. Tidak dipublikasikan.

Suparno, Mohamad Yunus. 2008. Keterampilan Dasar Menulis. Jakarta: Universitas Terbuka Departemen Pendidikan Nasional.

Waluyo, Herman J. 2002. Apresiasi Puisi Panduan untuk Pelajar dan Mahasiswa. Jakarta: PT. Gramedia Pustaka Utama.

*) Guru Bahasa Jawa SMP Negeri 1 Weleri Kendal 


\section{CURRICULUM VITAE PENELITI}

1. Nama

: Romdonah, S.Pd.

2. NIP

: 196809281990032006

NUPTK

: 1260746648300013

3. Tempat Tgl Lahir : Kendal, 28 September 1968

4. Jenis Kelamin : Perempuan

5. Pangkat/ Gol : Pembina, IV/a

6. Jabatan

: Guru Bahasa Jawa

7. Unit Kerja

: SMP Negeri 1 Weleri

8. Alamat Sekolah : Jalan Raya Timur 3 Weleri Kendal

Telepon/ Fax

: (0294) 642768

Website

: http://www.smpn1Weleri.sch.id

Email

:smpn1weleri@yahoo.co.id

9. Alamat Rumah

: Damarsari RT 06 RW 01 Cepiring Kendal

Email

: romdonahatmidi@gmail.com

Nomor HP

: 085226242525

10. Riwayat Pendidikan
a. SD Negeri 3 Cepiring
1981
b. SMP Negeri Cepiring
1984
c. SPG Negeri Semarang
d. IKIP Negeri Semarang (D2)
1989
e. IKIP Negeri Semarang (D3)
1997
f. Universitas Negeri Semarang (S1) 2000

11. Penelitian yang Pernah Dilaksanakan:

a. Upaya Peningkatan Keterampilan Membaca Huruf Jawa dengan Menggunakan Metode Lawaran pada Siswa Kelas VIIIB SMP Negeri 1 Weleri Tahun Ajaran 2008/2009

b. Peningkatan Keterampilan Menulis Huruf Jawa Melalui Media Kartalogi Pasangan pada Siswa Kelas VIIG SMP Negeri 1 Weleri Tahun Ajaran 2010/2011 